\title{
FinanCial IMPACT OF MENTAL ILLNESS AND How to MEASURE THE CONSEQUENCES
}

\author{
Benedikt Frank \\ Vysoká škola finanční a správní - University of Finance and Administration, \\ Estonská 500, 10100 Praha 10-Vršovice, Czech Republic \\ e-mail: 37216@mail.vsfs.cz
}

\begin{abstract}
This article shows the economic impact of mental illness, as well as various cost-estimating approaches. To assess the burden of mental diseases, there are three different ways: the human capital, the economic growth and the value of statistical life approach. The first focuses on indirect and direct costs. Moreover, the effect of mental illness on economic development can only be approximated implicitly. Thus, the lack of production is primary estimated for somatic conditions compared to their corresponding quantity of disabilityadjusted life years (DALYs). The total economic productivity drop associated with mental illnesses between 2011 and 2030 is rated to be US\$16.3 trillion globally. Furthermore, the value of statistical life (VSL) method suggests that trade-offs between risks and capital should be used to assess the probability of injury or death due to psychiatric illness. This computation is equivalent to that of cardiovascular disease and bigger than that of cancer. However, greater activism is required to better the existing condition.
\end{abstract}

\section{Keywords}

Economic costs; Economic growth; Human capital; Mental illness; Value of statistical life.

\section{Introduction}

Burnout has been characterized in a variety of ways [1] [2], but most scholars prefer a multifaceted concept that includes different features: emotional exhaustion, depersonalization, and diminished individual achievement [3]. The extent of emotional exhaustion applies to emotions of feeling jaded, over-extended, or the sense of being fatigued. Depersonalization corresponds to pessimistic and jaundiced behavior toward one's clients, colleagues or generally work. The shortened understanding of individual success includes furthermore pessimistic self-assessment of one's work with others or in general efficacy of the employment [4]. While there is often an association with burnout and other mental health problems, such as solicitude or depression, evidence further reinforces the fact that burnout differs from several mental ailments [5]. Nevertheless, the relationship and proximity to related research areas is given and partly blurred. Due to the lack of explicit literature on distinct macroeconomic consequences of burnout and also mental illness, the following article gives a general insight in the economic and social consequences of mental illness.

\section{$1 \quad$ Research Objectives}

The main aim of the article is to approach the economic impact of mental illness and to provide an overview of common methods of capturing economic consequences due to mental illness. Moreover, this article starts with an outline of previous figures and characteristics of mental illness and its economic impact. Further, different methods for determining and estimating the economic costs of mental illness are presented. In addition, the article 
addresses missed economic opportunities, the lack of current activity and improvement in the field of mental illness. Additionally, it comes to an evaluation of factors to be changed as well as a necessary paradigm shift in the attitude towards mentally ill people. It concludes with possible suggestions for improving the current situation.

\section{$2 \quad$ Mental Illnesses - An Underestimated Problem}

Every year about 165 million people in the European Union are affected by mental illnesses, mainly anxiety, mood, and drug use disorders [6], [7]. Altogether, 50 percent or more of people living in mid- and upper-income nations are troubled with not less than one psychiatric illness in their lifetime [8].

What do mental illnesses, for example, cost a nation? Healthcare expenses are perceived to be one of the biggest obstacles, for example, in U.S. public policy [9]. In 2006, healthcare expenses amounted to 16 percent from the nation's gross domestic product and a further increase was expected in the following years [10]. In 2019 the share of the health spending accounted for 17.7 percent of nation gross domestic product [11]. Studies of the Organisation for Economic Co-operation and Development (OECD) also valued the entire expenses of mental ill-health with approximately EUR600 billion in total or in percentage terms more than 4.0 percent of the gross domestic product (GDP) in each of the $28 \mathrm{EU}$ countries in 2018 . For example, the cost of mental problems in Germany is estimated at 4.8 percent of GDP [12].

Mental illnesses are also by no way restricted to a limited number of predisposed people but are a massive public health issue with important societal implications. They refer to extreme depression and functional disability, which are, in effect, mandatory medical conditions that could cause drastic effects not just for affected individuals. Even their families and their social and occupational surroundings get to feel the consequences [13]. 2010, psychiatric as well as substance use disorders accounted for 10.4 percent from worldwide strains of illness and were the main source of years of disabilities in all disease categories [7], [14]. More recent studies suggest that mental illnesses account for one-third of global sickness [15]. Furthermore, due to population trends and rising expectancy of life, the long-run incidence from mental illness is also projected to rise [13].

Patients and their social life are not limited to such consequences. They impact the whole social structure, in particular by economic costs. Appropriate calculation of these costs is complicated and difficult to render due to insufficient statistics. In addition, economic cost analyses differ substantially due to flaws in the description of diseases, demographics or tests analyzed, sources of cost and use of resources, methodological framework and inadequate cost descriptions due to lack of evidence and distinctions [16]. Even so, enhanced observational and financial approaches and patterns, along with greater detailed epidemiological evidence over the last 20 years, enable for an accumulation of more detailed and accurate data that gives us a better understanding of the extent of the economic effects of mental disorders. Although the majority of people believes that taking medicine, staying in a hospital or a clinical residence is a significant financial challenge of illness, in reality the hardship of illness - and especially of mental disorders - actually extends much deeper than these "direct" costs of diagnosis and care.

The World Economic Forum (WEF) identified three separate methods to assess the burden of economic diseases to understand more than just the "hidden costs" of illnesses. It is also about their effect on financial development within the macroeconomic scale [17]. 


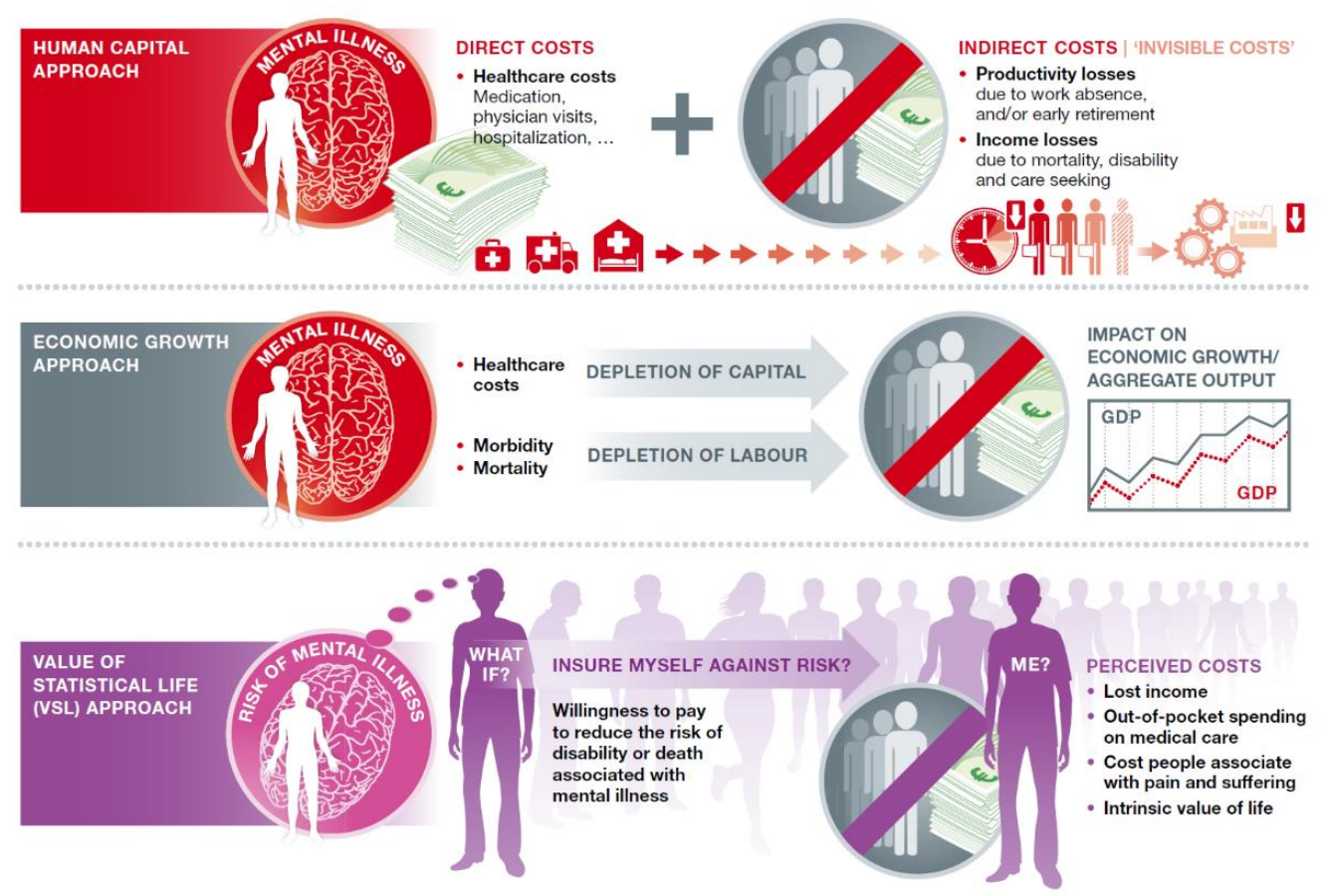

Source: [17]

Fig. 1: Various methods used to measure the economic effects of mental illness

\section{$3 \quad$ Human Capital Costs and Depressions}

The human capital approach is by far the widely applied measure for the financial effects of mental illnesses as well as diseases in general. It varies amongst indirect and direct costs. Direct costs are often referred to as the "visible costs" of care and recovery within the public health sector: medicine, doctor appointments, psychotherapy services, hospital stays, so forth. Indirect costs apply to the "invisible costs" correlated with loss of revenue because of death, injury and treatment, which includes the loss of productivity as a result of lack of employment or premature retirement [17], [18]. Another form of indirect cost is attributed to the large incidence of psychiatric intricacies linked with severe mental disorders, resulting in high levels of emergency room consultations, a large predominance of lung disease, so for example do individuals suffering severe mental problems consume 44 percent of the total cigarettes in the United States of America, and premature death, which is a reduction of 13 to 32 years of age. Furthermore, there are expenses associated with other effects, such as prison or homelessness, that are worth to be taken into account [19].

Thus, unlike most psychiatric ailments, the cost of psychiatric illnesses is "indirect" rather than "direct". Although indirect expenses were difficult to measure, they are crucial to influencing public policy. When the major elements of the economic impact of psychiatric illnesses are measured, more educated debates should be undertaken about what needs to be done in the prevention and care of these diseases [20].

It is assumed that the indirect effects and the effects of poverty on labor and thus on national production in terms of costs are 23 times greater compared to the charges that fall on the medical sector. Which is a major "hidden" influence, nevertheless it is hypothetically underestimated. A relevant review was delimited to adults and linked solitary to individuals who had been identified with depression and excluded social care and social security expenses. Otherwise, the review uses a human capital approach for pricing the lost employment, acknowledged to create fairly high forecasts from what is believed to be tough economic effects of value. Even after these nearly obvious limits, some reports not only 
include specific details of the cost effects of health services but also serve to point out that the consequences of depression are much more far-reaching [21]. Further research raises more intelligence on the relationship between depression and labor. So, anxiety and self-reported depression are the leading sources of absence from work in the United Kingdom [22]. Moreover, hidden effects of depression on decreased output at the workplace are an influence that cannot be accurately assessed by absenteeism figures [23]. Thirdly, a proof can be seen that relapses of depressive indications affect the employ status faster than use of health services [24]. Even though frequently debated in terms of reduced nation-wide output, the consequences of depression on employment are usually instantly felt by individuals suffering these diseases. Like for the majority, an employment is not just their primary foundation of earnings as well as retirement welfare benefits and, maybe, numerous marginal benefits, nevertheless, it also creates confidence, provides personal uniqueness, and widens social networks [25].

In addition, some studies concentrated particularly on a single cause of indirect costs: expenses of reduction of income. The research is founded on National Comorbidity Replication Surveys (NCS-R), a resident-based epidemiological investigation of psychiatric illnesses. In this study, results from approximately 5,000 persons had been utilized to measure the lost income by matching earnings in the prior twelve months of individuals with mental illnesses with twelve-month incomes of people with no mental issues. The research centered on people suffering from extreme mental disorders. The findings from [26], built on a universalized linear model examination, show a medium decrease in income of $\$ 16,306$ for people suffering from extreme psychiatric ailments, mutually without and with incomes, and also that around 75 percent from the overall decrease in earnings originated from people with any earnings the previous year relative to persons who had no incomes at all. In trying to extrapolate these distinct outcomes to the wider populace, the writers reported that severe psychiatric disorder is interrelated with a yearly harm in incomes amounting to $\$ 193.2$ billion. In addition, there remain many noticeable features in this article. Most of them is the gender gap in salaries: As the incomes of male individuals with extreme mental disorders fell to $\$ 28,070$ relative to men with no suffering from serious mental illness, those earnings were still higher than those of women without severe mental ailments. This finding cannot be clarified through a significant quantity of females external the workforce, since the study of those themes receiving good incomes showed just the similar significant gender-based income differences. The second unusual result is that earnings reductions are not solely a function of chronic unemployment [26]. Finally, as these findings are applied to the general public, the economic loss is significantly higher than the prior figures, which seem to be justified only marginally by inflationary factors [27].

To further approach this issue with a specific country: The existence of extreme anxiety and depression disorders has been linked with an annual substantial drop in income for both working and unemployed South African individuals. In person expense models, the total projected loss of revenue connected with extreme depression and anxiety disorders was $\$ 4,798$ per person per year, adjusted for age, ethnicity, drug misuse, occupation, family status, and household size at that time. Forecasts of the gross annual loss to South Africans coping with these diseases of missed revenue, generalized from the study, amounted to $\$ 3.6$ billion in that period [28].

Basically, two types of figures are required to measure the indirect and direct costs of the disease: epidemiological statistics on the occurrence of the condition, health treatment, related death, injury and, in some instances, incarceration and per patient expense of the disorder on the basis of economic statistics. Epidemiological information is usually relying on significant samples that notify prevalence ratios in given people and cohort investigations that relate the 
findings mentioned already. Price figures are typically extracted from experienced estimates, like mean hospital bed expense per night for emergency or mental institutions and are afterwards compounded by related epidemiological data [8].

Basing on figures by 2010, the worldwide indirect and direct financial costs of mental illness were evaluated at US\$2.5 trillion. Relevantly, the indirect costs of US\$1.7 trillion are far greater than the direct costs of US\$0.8 trillion, which contrasts with other primary illness classes, such as cardiovascular disease and cancer. The direct and indirect expenses have been calculated at EUR798 billion for the European Union, an area with highly advanced healthcare systems [18]. The direct and indirect expenses of psychiatric illness are anticipated to geminate by the year of 2030 [17]. Mentioned should be that these computations don't contain expenses allied with mental illnesses detached from the public health service, like legal expenses due to illegal substance exploitation [8].

\section{$4 \quad$ Missed Chances in Economic Expansion}

From a macro-economic viewpoint, the expense of mental illnesses in a given society can be enumerated as a reduction of economic production by calculating the potential effect of psychiatric conditions on the GDP [8]. The core concept behind this policy is that economic development relies on labor and financial resources, all of which may be adversely impacted by sickness. Capital is being decimated by health care spending and labor is being depleted by injury and death. Capital depreciation is measured on the basis of the savings rate data, care costs and the ratio of therapy expenses financed from personal savings. The effect on labor is calculated by contrasting the GDP to a counter-actual setup that implies no disease demises in contradiction of the predicted deaths' sickness. These rates of reduction of economic production are often estimated for corporal conditions and seldom for psychiatric disorders. Nevertheless, the effect of mental illness on economic development can only be approximated implicitly. Thus, the lack of economic production is primary estimated for somatic conditions compared to their corresponding quantity of disability-adjusted life years (DALYs). In the subsequent phase, the reduction of economic production for psychiatric illnesses is calculated based on the relative scale of the related DALYs for other illnesses [17]. There are studies which estimate the total economic production decline connected with mental conditions between 2011 and the year 2030 to be US\$16.3 trillion globally. This relates the economic productivity damage assimilable with psychiatric disorders equal to those of cardiovascular issues and greater than that of cancer, diabetes, and chronic respiratory diseases [8].

\section{$5 \quad$ Evaluation by Value of Statistical Life}

The value of statistical life (VSL) method is the widest technique used to measure the economic effects of mental illness. This approach suggests that trade-offs between risks and capital should be used to assess the probability of injury or death due to psychiatric illness. This quantification study reveals trade-offs or theoretical expectations, such as results from polls, which questioned people what they'll be willing to spend to escape a specific hazard, as well as how much funding they would actually require taking on that threat [17]. The VSL is then determined on the basis of these arbitrary risk-value ratios. Suppose, for instance, that the overall lifetime chance of deceasing from depressive illness is 15 in 1,000. Assume, however, that there are steps that might decrease that chance to 5 in 1,000 .

If citizens of a particular demographic are able to pay a mean of US\$50,000 on these steps, the estimated VLS will be US\$5 million for that population to be reproduced with the calculation (1).

$$
\mathrm{US} \$ 50,000 /[(15-5) / 1,000]
$$


A similar reasoning can likewise be used by considering the ability to sacrifice monetarily to no longer struggle with a particular illness. As a consequence, the VSL strategy not just accounts for missed revenue and expenditure on information, prescriptions and treatment, but also for the expenses associated with injury and suffering. Applying the VSL method, the worldwide financial cost of mental illness was calculated to be US\$8.5 trillion in 2010. Alike the economic increase effect, this calculation is equal to that of cardiovascular ailments and greater than that of chronic respiratory issues, cancer, and diabetes. The economic pressure is also projected to nearly duplicate by 2030 [17]. In brief, mental illnesses inflict immense monetary costs, directly through comparatively low treatment costs, and indirectly through proportionately high productivity reductions and commercial growth impacts. This sample of comparatively little direct against considerably large indirect costs varies from nearly all other disability classes, although the entire spectrum of psychiatric illnesses has rarely been taken into consideration. As this estimated scale of economic losses relies on the analytical method, available figures from year 2010 suggest that the burden of psychiatric illnesses can be calculated at US $\$ 2.5$ trillion by means of the conventional human capital method, or US $\$ 8.5$ trillion using a willingness to pay approach, recognizing that global health investment in 2009 was around US\$5 trillion [8] [17]. Mental illnesses therefore cost more than chronic somatic conditions, such as diabetes and cancer, and the expenses are predicted to rise exponentially by 2030 [8].

\section{$6 \quad$ Missing Activity}

The previous overview of the worldwide economic burdens of mental illness is substantiated by various national surveys and an EU-wide report by the European Brain Council [18]. Questionable here is how these studies have been interpreted and why the legislation has modified the amount of support for prevention, diagnosis, and care. Nevertheless, psychiatric and substance use issues are frequently not part of existing medical care programs [29]. Although these methods are considered universal health services, they restrict psychiatric or drug use conditions. These circumstances continue even as the respective health interferences at the populace level, such as the disposability of alcohol, the community rate, such as school life skills instruction and the level of health services, are successful and can be properly enforced. Furthermore, their adoption is mostly cost-effective, but the care deficit for psychiatric and substantive use problems is greater than in any other health field. Ability to psychiatric health care is typically minimal due to limited staff and facilities, and appropriate evidence-based services are not offered. Crucially, there is nearly no particular prevention, with many high-income countries having no exception. This brings up the question as to the causes for these extraordinary disparities and the apparent lack of political engagement to fix the issue. Firstly, it should be recognized that the advancement and application of reliable and successful diagnosis and recovery strategies for mental wellbeing is only at a comparatively early level, and so numerous evidence-based therapies and treatments have just been accessible in the last 30 years. Capacity building regarding manpower, facilities and other services is also well behind other illness fields. Above all, there might be a speculation that stigmatization and misbelief about both psychiatric and addiction problems continue to be a significant part. This is not just non-professionals who tend to think that mental and drug use conditions are not actual illnesses, that they cannot be cured adequately, and that those suffering are at any rate partially liable. As a result, cultures are likely to invest far more on somatic ailments than on psychiatric illnesses, even if the mortality and economic effects are in minimum as high as those incurred by somatic problems [8]. For instance, research reveals the existing public opinion on the distribution of capital. Relying on a survey from the general population of Germany, adolescents were allowed to pick three out of nine medical problems for which they would choose services not to be decreased if broad reductions in the health 
budget were required. Around two-thirds of participants listed cancer as a medical disorder that has to be protected from decreases, accompanied by AIDS, diabetes, and myocardial infarction. Just a limited number of participants related to psychiatric illnesses, such as depression and schizophrenia [30].

Beyond the influence of public sentiment, financing policies in certain cultures remain centered on lethality and life expectancy, and although psychiatric illnesses not directly lead to a high degree of fatalities, they seldom feature on mortality data. In the end, it does not appear to be widely understood that mental illnesses are overwhelmingly contributing to socalled high-cost consumers of our medical scheme [8].

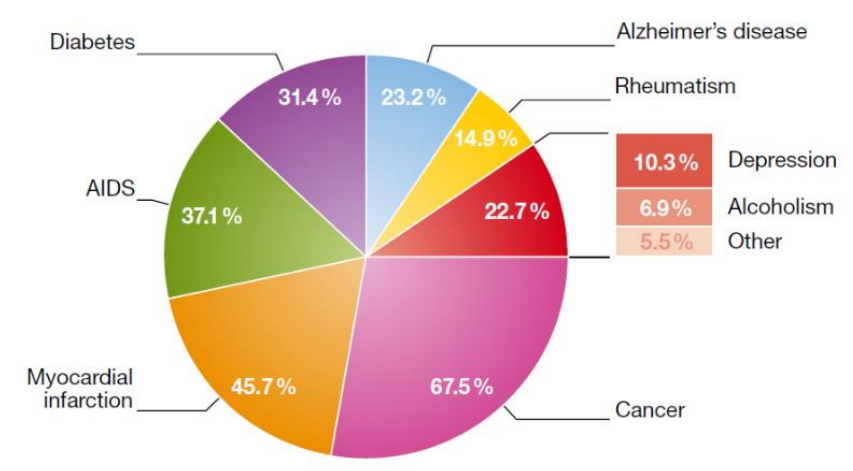

Source: [30]

Fig. 2: In the event of general cutbacks within the healthcare budget, medical problems on which services should not be cut. Results are in percentages, multiple responses were allowed.

\section{$7 \quad$ Need for Improvement and Required Changes}

Owing to the aforementioned factors, the ongoing lack of funding in mental health services is likely to continue without reconsidering the expense of mental illness, the cost savings of medication and prevention treatments, and the necessity for a substantive improvement of stigmatization [8]. While signs of large-scale interventions to change this condition have begun to appear [31], culture, policymakers and stakeholders must be continuously and repeatedly educated about the actual rate of mental illness, such as personal strains and the full spectrum of future economic consequences. Yet another priority must be on the efficacy, viability and affordability of interventions to reduce that strain. If these steps persist, people will potentially be more likely to agree that investing resources on prevention and treatment of mental illnesses is a reasonable expenditure [8].

Frequently fundamental non-health expenditures are not superficial ornaments in extensive scholarly research. Nor are the analysts' plots expected to cost. These are the current strains on capabilities that must be endured by individuals or members of society. Productiveness losses for the economy had exceeded a relative scale, but the resulting lack of profits for individuals with depression may have suffered serious harm. More focus should be given to the first step in the study of transition, which shows us the full scale and extent of the economic effects of these diseases. In addition, there is a demand for cost-effectiveness and related assessments that team expenses with information on the effects. The concern, though, is that so many analyses are very limited in their costing and sometimes performance. In reality, medical providers actually consider some non-health implications of psychiatric disease, such as the motivation of a client to return to work before making decisions. Nevertheless, as achievement evaluation not only becomes more widespread, but also brings benefits and fines, it will get more and more difficult for such practitioners to make choices 
that preserve someone else's resources, particularly patients, at the expense of the assets of their own department. Child and youth mental health providers can do what they can to handle mental disabilities regarding their limited funds. This is at the heart of the matter. Studies can only explain that care providers and their managers could only do as much as their resources and success evaluation systems enable. Efficient steps can mostly be done at the federal level in general, which also implies at the point of particular government facilities fixing incentives that otherwise discourage organizations from doing what is better for patients at the rate that is more cost-effective for society. Politicians have, in turn, to consider the distributional effects of diverse mental health policies in real life. Quite broadly, whether mental disease is more common in low-income communities and whether concealed individual and family consequences are overlooked as policy - or implementation adjustments are made - or whether possible new innovations are rejected, the question arises if this would not contribute to the socioeconomic isolation of already disadvantaged groups. Moreover, individuals with mental health issues also have a wide variety of requirements. In conclusion, it is essential that the expense of their treatment is broadly similar if policy and procedure are to develop either their efficacy and their distributional implications [25].

\section{Conclusion}

On the basis that every year a large number of people suffer from mental illness, the preceding article shows, that these diseases are a heavily public health issue that has significant societal implications. Three different ways were described to assess the economic impact of mental illness on society: the human capital approach, the economic growth approach and the value of statistical life approach use different ways of estimating economic consequences. The first deals with the direct and indirect costs of mental illness, while the second takes a closer look at the depletion of capital and the depletion of labor. Finally, the latter tries to analyze the willingness to pay, which deals with the perceived investment that people would be willing to make in order to avoid, for example, a mental illness. To improve the current situation, however, increased activism is needed. A mindset away from the stigmatization of the mentally sufferers must become established. After all, it is not only lay people who condemn mental disease. So, this is one reason why the resources for dealing with mental problems are still severely limited. Due to the fact that studies have recognized the still insufficient awareness of the urgency in the broader society for psychiatric issues, it is in conclusion important to note that changes must also be initiated and supported by governments in particular in order to achieve sustainable and effective improvements. For it is likely that mental health services will continue to be underfunded without deeper consideration of cost savings in medications, the cost of mental illness in general, and preventive treatments. Because always it should be the main aim to preventively counteract mental illnesses, to minimize the suffering of individuals with psychiatric disorders and even to be able to cure them - with possibly even positive consequences for further economic growth.

\section{Literature}

[1] CHERNISS, C.: Professional Burnout in Human Service Organizations. Praeger, New York, 1980.

[2] ARONSON, E.; PINES, A. M.; KAFRY, D.: Ausgebrannt. Vom Überdruß zur Selbstentfaltung. Klett-Cotta, Stuttgart, 1983.

[3] MASLACH, C.: Job burnout. How people cope. Public Welfare. 1978, Vol. 36, pp, 5658. 
[4] STALKER, C.; HARVEY, C.: Professional burnout: A review of theory, research, and prevention. Wilfrid Laurier University, Waterloo, 2002.

[5] MASLACH, C.; SCHAUFELI, W. B.: Job burnout. Annual Review of Psychology. 2001, Vol. 52, pp. 397-422.

[6] KESSleR R. C.; PETUKHOVA, M.; SAMPSON, N. A.; ZASLAVSKY, A. M.; WITTCHEN, H.-U.: Twelve-month and lifetime prevalence and lifetime morbid risk of anxiety and mood disorders in the United States. International Journal of Methods in Psychiatric Research. 2012, Vol. 21, Issue 3, pp. 169-184. DOI: 10.1002/mpr.1359

[7] WITTCHEN, H.-U.; JACOBI, F.; REHM, J. et al.: The size and burden of mental disorders and other disorders of the brain in Europe 2010. European Neuropsychopharmacology. 2011, Vol. 21, Issue 9, pp. 655-679. DOI: 10.1016/j.euroneuro.2011.07.018

[8] TRAUTMANN, S.; REHM, J.; WITTCHEN, H.-U.: The economic costs of mental disorders: Do our societies react appropriately to the burden of mental disorders? EMBO Reports. 2016, Vol. 17, Issue 9, pp. 1245-1249. DOI: 10.15252/embr.201642951

[9] CATLIN, A.; COWAN, C.; HARTMAN, M.; HEFFLER, S.: National Health Spending in 2006: A Year of Change for Prescription Drugs. Health Affairs. 2008, Vol. 27, Issue 1, pp. 14-29. DOI: $\underline{10.1377 / \text { hlthaff.27.1.14 }}$

[10] POISAL, J. A.; TRUFFER, Ch.; SMITH, S.; SISKO, A.; COWAN, C.; KEEHAN, S.; DICKENSHEETS, B.: Health spending projections through 2016: modest changes obscure part D's impact. Health Affairs. 2007, Vol. 26, Issue 2, pp. 242-253. DOI: $10.1377 /$ hlthaff.26.2.w242

[11] MARTIN, A. B.; HARTMAN, M.; LASSMAN, D.; CATLIN, A.: National Health Care Spending In 2019: Steady Growth For The Fourth Consecutive Year. Health Affairs. 2020, Vol. 40, Issue 1, pp. 14-24. DOI: 10.1377/hlthaff.2020.02022

[12] OECD: Mental health problems costing Europe heavily. [online]. 2018. Available from WWW:

http://www.oecd.org/health/mental-health-problems-costing-europeheavily.htm

[13] PATEL, V.; CHISHOLM, D.; PARIKH, R.; CHARLSON, F. J.; DEGENHARDT, L.; DUA, T.; FERRARI, A. J.; HYMAN, S.; LAXMINARAYAN, R.; LEVIN, C et al.: Global Priorities for Addressing the Burden of Mental, Neurological, and Substance Use Disorders. In: Patel, V.; Chisholm, D.; Dua, T.; Laxminarayan, R.; Medina-Mora, M. E. (eds.), Mental, Neurological, and Substance Use Disorders: Disease Control Priorities. Third Edition (Volume 4). The World Bank. Washington, DC, 2016.

[14] WHITEFORD, H. A.; DEGENHARDT, L.; REHM, J.; BAXTER, A. J.; FERRARI, A. J.; ERSKINE, H. E.; CHARLSON, F. J.; NORMAN, R. E.; FLAXMAN, A. D.; JOHNS, N. et al.: Global burden of disease attributable to mental and substance use disorders: findings from the Global Burden of Disease Study 2010. Lancet. 2013, Vol. 382, Issue 9904, pp. 1575-1586. DOI: 10.1016/S0140-6736(13)61611-6

[15] VIGO, D.; THORNICROFT, G.; ATUN, R.: Estimating the true global burden of mental illness. The Lancet Psychiatry. 2016, Vol. 3, Issue 2, pp. 171-178. DOI: $\underline{10.1016 / \mathrm{S} 2215-0366(15) 00505-2}$

[16] HU, T.: An international review of the economic costs of mental illness. Berkeley: University of California, 2004. 
[17] BLOOM, D. E.; CAFIERO, E. T.; JANÉ-LLOPIS, E.; ABRAHAMS-GESSEL, S.; BLOOM, L. R.; FATHIMA, S.; FEIGL, A. B.; GAZIANO, T.; MOWAFI, M.; PANDYA, A.; PRETTNER, K.; ROSENBERG, L.; SELIGMAN, B.; STEIN, A. Z.; WEINSTEIN, C.: The Global Economic Burden of Non-communicable Diseases. [online]. World Economic Forum, Geneva, 2011. Available from WWW: https://www3.weforum.org/docs/WEF_Harvard_HE_GlobalEconomicBurdenNonCom municableDiseases_2011.pdf

[18] GUSTAVSSON, A.; SVENSSON, M.; JACOBI, F.; ALLGULANDER, Ch.; ALONSO, J.; BEGHI, E.; DODEL, R.; EKMAN, M.; FARAVELLI, C.; FRATIGLIONI, L. et al.: Cost of disorders of the brain in Europe 2010. European Neuropsychopharmacology. 2011, Vol. 21, Issue 10, pp. 718-779. DOI: $10.1016 /$ j.euroneuro.2011.08.008

[19] COLTON, C. W.; MANDERSCHEID, R. W.: Congruencies in increased mortality rates, years of potential life lost, and causes of death among public mental health clients in eight states. Preventing Chronic Disease. 2006, Vol. 3, Issue 2, pp. 1-4.

[20] INSEL, T. R.: Assessing the Economic Costs of Serious Mental Illness. The American Journal of Psychiatry. 2008, Vol. 165, pp. 663-665. DOI: $\underline{10.1176 / \text { appi.ajp.2008.08030366 }}$

[21] THOMAS, Ch. M.; MORRIS, S.: Cost of depression among adults in England in 2000. The British Journal of Psychiatry. 2018, Vol. 183, Issue 6, pp. 514-519. DOI: $10.1192 / 00-000$

[22] ALMOND, S.; HEALEY, A.: Mental health and absence from work: New evidence from the UK Quarterly Labour Force Survey. Work, Employment and Society. 2003, Vol. 17, Issue 4, pp. 731-742. DOI: $\underline{10.1177 / 0950017003174007}$

[23] KESSLER, R. C.; GREENBERG, P. E.; MICKELSON, K. D.; MENEADES, L. M.; WANG, P. S.: The effects of chronic medical conditions on work loss and work cutback. Journal of Occupational and Environmental Medicine. 2001, Vol. 43, Issue 3, pp. 218-225. DOI: 10.1097/00043764-200103000-00009

[24] SIMON, G. E.; REVICKI, D.; HEILIGENSTEIN, J.; GROTHAUS, L.; VonKORFF, M.; KATON, W. J. et al.: Recovery from depression, work productivity, and health care costs among primary care patients. General Hospital Psychiatry. 2000, Vol. 22, Issue 3, pp. 153-162. DOI: 10.1016/S0163-8343(00)00072-4

[25] KNAPP, M.: Hidden costs of mental illness. The British Journal of Psychiatry. 2003, Vol. 183, Issue 6, pp. 477-478. DOI: 10.1192/03-292

[26] KESSlER, R. C.; HEERINGA, S.; LAKOMA, M. D.; PETUKHOVA, M.; Rupp, A. E.; SCHOENBAUM, M.; WANG, P. S.; ZASLAVSKY, A. M.: Individual and Societal Effects of Mental Disorders on Earnings in the United States: Results From the National Comorbidity Survey Replication. The American Journal of Psychiatry. 2008, Vol. 165, Issue 6, pp. 703-711. DOI: 10.1176/appi.ajp.2008.08010126

[27] HARWOOD, H.; AMEEN, A.; DENMEAD, G.; ENGLERT, E.; FOUNTAIN, D.; LIVERMORE, G.: The Economic Cost of Mental Illness. National Institute of Mental Health, Rockville, Maryland, 1992.

[28] LUND, C.; MYER, L.; STEIN, D. J.; WILlIAMS, D. R.; FLISHER, A. J.: Mental illness and lost income among adult South Africans. Social Psychiatry and Psychiatric Epidemiology. 2013, Vol. 48, Issue 5, pp. 845-851. DOI: 10.1007/s00127-012-0587-5 
[29] CHISHOLM, D.; JOHANSSON, K. A.; RAYKAR, N.; MEGIDDO, I.; NIGAM, A.; STRAND, K. B.; COLSON, A.; FEKADU, A.; VERGUET, S.: Universal Health Coverage for Mental, Neurological, and Substance Use Disorders: An Extended CostEffectiveness Analysis. In: Patel, V.; Chisholm, D.; Dua, T.; Laxminarayan, R.; Medina-Mora M. E. (eds.), Mental, neurological, and substance use disorders. The World Bank, Washington, DC, 2016. DOI: 10.1596/978-1-4648-0426-7_ch13

[30] SCHOMERUS, G.; MATSCHINGER, H.; ANGERMEYER, M. C.: Alcoholism: Illness beliefs and resource allocation preferences of the public. Drug and Alcohol Dependence. 2006, Vol. 82, Issue 3, pp. 204-210. DOI: 10.1016/j.drugalcdep.2005.09.008

[31] HARO, J. M.; AYUSO-MATEOS, J. L.; BITTER, I.; DEMOTES-MAINARD, J.; LEBOYER, M.; LEWIS, S. W.; LINSZEN, D.; MAJ, M.; McDAID, D.; MEYERLINDENBERG, A. et al.: ROAMER: roadmap for mental health research in Europe. International Journal of Methods in Psychiatric Research. 2014, Vol. 23, pp. 1-14. DOI: $\underline{10.1002 / \mathrm{mpr} .1406}$ 


\section{FINANČNÍ DOPAD DUŠEVNÍCH CHOROB A JAKÝM ZPU゚SOBEM MĚŘIT JEJICH}

\section{NÁSLEDKY}

Tento článek ukazuje ekonomický dopad duševních onemocnění a také různé př́istupy $\mathrm{k}$ odhadu nákladů. $\mathrm{K}$ posouzení zátěže duševních chorob existují tř̆i různé způsoby: lidský kapitál, ekonomický růst a hodnota statistického př́stupu k životu. První se zaměřuje na neprímé a prímé náklady. Navíc vliv duševních chorob na ekonomický rozvoj lze pouze implicitně přibližit. Nedostatek produkce se tedy primárně odhaduje pro somatické stavy ve srovnání s jejich odpovídajícím počtem let života upravených na zdravotní postižení (DALY). Celkový pokles ekonomické produktivity spojený s duševními chorobami mezi lety 2011 a 2030 je celosvětově ohodnocen na 16,3 bilionu USD. Metoda hodnoty statistického života (VSL) dále naznačuje, že $\mathrm{k}$ posouzení pravděpodobnosti zranění nebo úmrtí v důsledku psychiatrického onemocnění by měly být použity kompromisy mezi riziky a kapitálem. Tento výpočet je ekvivalentní výpočtu kardiovaskulárního onemocnění a je větši než výpočet rakoviny. Ke zlepšení stávajícího stavu je však zapotřebí většího aktivismu.

\section{FinANZIELLE AUSWIRKUNG AUf GEISTESKRANKHEITEN UND WEGE, DIE KONSEQUENZEN ZU MESSEN}

Dieser Artikel legt die ökonomische Auswirkung von Geisteskrankheiten sowie die verschiedenen Ansätze zur Kostenrechnungen dar. Um die Belastung von Geisteskrankheiten zu beurteilen, gibt es verschiedene Wege: das menschliche Kapital, das ökonomische Wachstum und der Wert und die statistische Lebensdauer. Der erste Weg zielt auf die direkten und die indirekten Kosten. Darüber hinaus kann die Auswirkung von Geisteskrankheiten auf die wirtschaftliche Entwicklung nur annäherungsweise erschlossen werden. Daher wird das Fehlen von Produktion als ausschlaggebend für die somatischen Gegebenheiten betrachtet. Diese werden mit ihrer entsprechenden Quantität von behinderungsgerechten Lebensjahren verglichen (DALYs). Der Abfall der totalen ökonomischen Produktivität wird unter Heranziehung von Geisteskrankheiten zwischen 2011 und 2030 auf 13,3 Billionen US-Dollar veranschlagt. Weiter legt der Wert der statischen Lebensdauer nahe, dass ein Ausgleich zwischen Risiko und Kapital zur Beurteilung der Wahrscheinlichkeit von Verletzungen oder Todesfällen auf Grund von Geisteskrankheiten angewendet werden sollte. Diese Berechnung entspricht derjenigen einer kardiovaskularen Krankheit und noch mehr einer Krebserkrankung. Gleichwohl ist ein größerer Aktivismus erforderlich, um eine Besserung der bestehenden Bedingungen herbeizuführen.

\section{WPŁYW FINANSOWY CHORÓB PSYCHICZNYCH I SPOSÓB POMIARU ICH SKUTKÓW}

W niniejszym artykule przedstawiono ekonomiczny wpływ chorób psychicznych, a także różne podejścia do szacowania kosztów. Istnieją trzy różne sposoby, by ocenić obciążenie chorobami psychicznymi: kapitał ludzki, wzrost gospodarczy i wartość statystycznego życia. Pierwszy skupia się na kosztach pośrednich i bezpośrednich. Ponadto wpływ chorób psychicznych na rozwój gospodarczy można określić jedynie w sposób domniemany. Dlatego też brak produkcji jest szacowany przede wszystkim dla schorzeń somatycznych $w$ porównaniu $\mathrm{z}$ odpowiadającą im liczbą lat życia skorygowanych niepełnosprawnością (DALY). Całkowity spadek wydajności ekonomicznej związany z chorobami psychicznymi w latach 2011-2030 szacuje się na 16,3 biliona USD w skali globalnej. Ponadto, metoda wartości statystycznego życia (VSL) sugeruje, że do oceny prawdopodobieństwa urazu lub śmierci z powodu choroby psychicznej należy stosować kompromisy między ryzykiem a kapitałem. Obliczenia te są równoważne z obliczeniami dotyczącymi chorób sercowo-naczyniowych i są większe niż w przypadku nowotworów. Jednakże, aby poprawić istniejący stan, konieczna jest większa aktywizacja. 